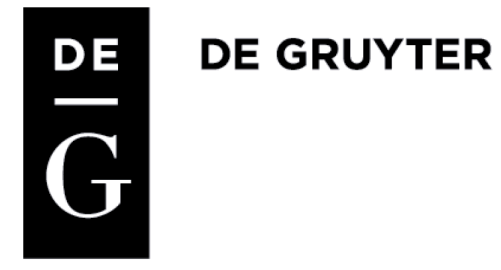

Lucyna Błażejczyk-Majka (Adam Mickiewicz University, Poznań)

\title{
APPLICATION OF DEA FOR EVALUATING THE EFFICIENCY OF ECONOMIC POLICY AS EXEMPLIFIED BY EU AGRICULTURE
}

The article presents how DEA is used to develop agricultural production efficiency rankings in the EU member states, which can be used as the starting point for evaluating the performance of currently used instruments of economic policy. In the article, statistical data from the FADN were used. Agricultural production was compared for three types of output and four types of input involved. The performed study demonstrated that in 18 out of 28 states, agricultural production had been run efficiently on a macro level. The applied approach also allowed for identifying the causes of inefficiency in the remaining ten states, providing indications for recommended changes in in the way economic instruments are used.

Keywords: economic policy, DEA, technical efficiency, agriculture of the EU doi:10.1515/sho-2017-0011

\section{INTRODUCTION}

In modern economic history, the evaluation of efficiency remains one of the most complex problems. It is conducted in order to assess the quality of production, management, and investment, as well as that of particular stages of the production process. Such studies are considered particularly significant for analyzing the economic conditions, especially in those sectors of macroeconomic production which are supported by various economic policy instruments.

In the European Union (EU), the Common Agricultural Policy (CAP) has been implemented since the early 1960s. Its aim is to provide EU citi- 
zens with enough food at adequate prices and guarantee that farmers can lead their lives at a satisfactory level [Ackrill R. 2000: 15-45]. In the 1970s, expenditure on the CAP constituted 70\% of the whole EU budget, which clearly shows how important it is for the EU. Subsequent reforms of the CAP aimed at reducing this number. At present, the CAP consumes around 38\% of the entire EU budget [The Common Agricultural Policy in figures 2017].

Due to its social character and the principles of the EU, the introduction of any changes within the CAP requires detailed analyses of the economic standing of agricultural holdings in all member states. Therefore, the European Commission created a system for collecting accounting data from agricultural holdings, namely the Farm Accounting Data Network [FADN, http:/ / www.ec.europa.eu/agriculture/rica]. This system allows for determining the actual economic situation of agricultural holdings. These data are also used to evaluate the effectiveness of the invested EU means and to set directions for systemic changes.

One of the quantitative tools for evaluating the effects of economic policy are rankings. For economic analyses, the most important rankings are those that take into consideration the economic efficiency of the studied entities. Rankings can be univariate, i.e. developed based on one product (output) and one production factor (input). However, the area of comparison is usually determined by its multivariate character. Efficiency rankings that simultaneously include many types of outputs from the production process and many types of input involved may be developed by applying non-parametric methods. One such method is Data Envelopment Analysis (DEA), well-known in economic literature.

The problem seems to be important, as the EU policy (in particular the $\mathrm{CAP}$ ) changes along with the new financial perspectives. In order to assess the process objectively so as to indicate new directions of economic policy, it is crucial to constantly analyze the achieved goals and compare them with expenditure using historical data. Therefore, the aim of the article is to demonstrate the possibility of applying the DEA method as a starting point for evaluating the situation of various subjects of social and economic life, particularly in EU agriculture. The example presented in the present article takes into consideration three groups of outputs produced in the agricultural production process, four basic production factors (inputs) involved, and an assumption of variable returns to scale. The presentation of DEA principles was based on data on agricultural production in EU member states for the year 2012. These data were published by the FADN statistical agency. 


\section{MULTI-VARIATE RANKINGS}

The simplest method of developing multi-variate rankings is to apply ratio analysis methods that involve calculating the mean (arithmetic mean or weighted arithmetic mean) efficiency for each of the factors involved in the production process [Wroński P. 2011: 39-47]. In this approach, comparisons can be made only for one product, described by multiple characteristics. Use of the mean efficiency for more than one product is debatable due to the problems of comparability. Furthermore, a ranking developed this way assumes that the studied entities were capable of achieving the same level of efficiency regardless of the level of production, so it assumes constant returns to scale. Such assumption means that the most efficient entity of all is the one with the highest average productivity. If one assumes that the studied entities can operate under the conditions of variable returns to scale, the most efficient entities are those which, at a specific production level, generate the smallest individual cost or the largest output per unit of input. In contrast to the assumption on constant returns to scale, there are usually several such entities. More on associations between the returns to scale and the efficiency of the studied entities can be found in the chapter "The Variable Return to Scale Model and Scale Efficiencies" [Coelli T., Rao P., O'Donnell C., Battese G. 2005: 172-179].

Rankings developed based on constant returns to scale only offer a limited view of the economic reality, particularly with regard to agricultural production. Diversification of returns to scale can be achieved through the application of a parametric approach for developing the ranking [see for instance Aigner D., Chu S. 1968: 826-839; Afriat S. 1972: 568-598]. This approach uses estimations of production functions. Due to the natural character of the production process, comparisons that assume variable returns to scale seem more appropriate.

Another problem in efficiency analyses is the number of the analyzed outputs of the compared entities. Most parametric analysis methods based on the production function are limited to one type of output. Usually in such a situation the total production from various sectors is used, expressed in monetary units. This method entails omitting some information that distinguishes the specific entities. Efficiency rankings that simultaneously include many types of outputs from the production process and variable returns to scale may be developed by applying non-parametric methods [see for instance Farrell M., 1957:253-281; Charnes A., 
Cooper W., Rhodes E. 1978: 429-444], and in particular the DEA method, well known both in Polish and foreign literature [see for instance Świtłyk M. 1999:28-41; Førsund F., Sarafoglou N. 2002: 23-40; Lisowski M. 2014: 364-375; Scippacercola S., Sepe E. 2014:1-9; Zhang W. 2015: 414-416]. This method produces a ranking of technical efficiency where each entity is scored between 0 and 1 . Based on this method it is possible to determine the efficiency of entities producing many types of output, assuming constant or variable returns to scale. This method can evolve into a superefficiency model [see e.g. Błażejczyk-Majka L. 2016: 20-34].

As opposed to other methods used for developing rankings, DEA also allows for identifying the causes of inefficiency in the case of inefficient entities. Therefore, apart from determining the position in the ranking, it is possible to present recommendations for changes aiming at achieving full efficiency. Furthermore, an extensive report generated based on this analysis allows to assign each inefficient entity (one that has not achieved the highest efficiency) a "leader", i.e. an efficient entity that operates under similar conditions and should be followed.

\section{DATA ENVELOPMENT ANALYSIS (DEA)}

Data envelopment analysis (DEA) involves solving a series of linear equations, which are then used to identify the limit of maximum technical efficiency [see more in the works of Koopsans T. 1951 and Debreu G. 1951:14-22]. Vectors of outputs and inputs are compared in all studied entities. The only condition that must be met in this analysis is the type of technology. It can be based on constant returns to scale (CRS) or variable returns to scale (VRS). For the analysis, it is also necessary to define the orientation of production in each entity, which might involve output maximization or input minimization. The method is described in detail in books by Coelli T., Rao P., O’Donnell C., Battese G. [2005: 172-179] and Thanassoulis E., Portela M., Despić O. [2008].

If one assumes that production involves constant returns to scale and is oriented towards output maximization with given inputs, the technical efficiency of each entity against all entities in the sample is determined by solving the following linear equations:

$$
\max _{\theta, \lambda} \theta_{i^{\prime}} \quad \boldsymbol{Y} \lambda \geq \theta_{i} y_{i^{\prime}} \quad x_{i} \geq X \lambda, \quad \lambda \geq 0
$$


where $\mathbf{x}_{i}$ and $\boldsymbol{y}_{i}$ are the vectors of inputs and outputs, respectively, of the $i^{\text {th }}$ entity. $X$ and $Y$ are matrices of inputs and outputs, taking into account all entities in the study. The technical efficiency of the $i^{\text {th }}$ entity $\left(\operatorname{TE}_{C}(i)\right)$ is a reverse optimum value $\theta_{i^{\prime}}$ determined based on the solution of the linear program. If $\mathrm{TE}_{\mathrm{C}}(i)$ equals one, this means that the $i^{\text {th }}$ entity has the highest efficiency in the whole group - it is the leader, a model entity. More on measuring and interpreting efficiency can be found in the monograph by H. Fried, K. Lovell and S. Schmidt [2008].

If one assumes VRS in the production, then the above linear program must be complemented with an additional assumption that the sum of all $\lambda$ is 1 . Technological efficiency calculated this way for the $i^{\text {th }}$ entity $\left(\operatorname{TE}_{\mathrm{V}}(i)\right)$ cannot be smaller than $\mathrm{TE}_{\mathrm{C}}(i)$. If the ratio of both efficiencies $\mathrm{TE}_{\mathrm{C}}(i) / \mathrm{TE}_{\mathrm{V}}(i)$ equals 1 , then this entity operates at the optimum scale.

To sum up, DEA allows for determining the technical efficiency of every entity in the sample. Based on these values, it is possible to develop a ranking of entities, in which the leaders (model entities) are characterized by efficiency $\operatorname{TE}_{\mathrm{v}}(i)=1$, while other entities have efficiencies between 0 and 1 . If, with those assumptions in mind, a sample entity achieves the efficiency of 0.9 , it means that using a given technology, this entity could produce $10 \%$ more output with the same input.

On the other hand, analyzing the values of vectors $\lambda$ for the entities whose technological efficiency was lower than one, allows for indicating the closest leaders, taking into consideration the relationship between the size of output and the size of input [Coelli T., Rao P., O'Donnell C., Battese G. 2005: 166-167]. Here, it is worth noting that the values themselves do not hold any economic interpretation. They are only weights used to determine the potential production of an inefficient entity. The DEA method also allows for determining the type of returns to scale. They can be increasing, decreasing, or constant (IRS, DRS, CRS respectively). This characteristic is the basis for testing local returns to scale, for instance [Löthgren M., Tambour M. 1999: 449-458].

The DEA method has some disadvantages related to the use of linear programming for efficiency analysis. The nonparametric maximum efficiency limit is only linear in segments. In some cases, this poses difficulties in determining efficiency levels. Problems arise when in some segments, the maximum efficiency limit is parallel to the axis. In such a situation, the so-called "input slack" may be observed for some entities. This happens when an entity consumes too much input, and a certain limitation of input does not change the size of its output. Output slack can also occur, 
which means that with a given technology, an entity could achieve a higher output without consuming more input. Such problems are not present in most parametric functions. Another disadvantage of the method is the fact that results cannot be generalized, as is the case with parametric methods. For these reasons, the DEA method should be used for making comparisons between entities, for example for developing rankings, rather than for characterizing economic processes.

Linear combinations based on the values of coefficients $\lambda$, along with the assessment of input and output slacks, allows one to determine the direction of changes that an entity should implement to improve its efficiency. The occurrence of an output slack for one of the entity's products demonstrates by how much the production of this product should be increased, in absolute units. The occurrence of an input slack means that the size of input should be adjusted by the estimated value of this index, which is also expressed in absolute units.

Notably, DEA is available in many commercial statistical programs [see e.g.: http://www.deafrontier.net/deafree.html; http://www.deaanalysis.com/data-envelopment-analysis-software/data-envelopmentana lysis.html]. A non-commercial version of the DEAP software, created specifically for this method, can be downloaded from the website of the Center for Efficiency and Productivity Analysis (CEPA, 2016). Apart from the software, the website also offers an extensive description and a user's manual.

\section{DATA}

In order to illustrate the presented method, country-level statistical data on agricultural production published by the FADN agency are used. The selection of variables, particularly in the area of input, tends to be problematic for researchers. B. Guzik [2009] wrote extensively on various approaches in this area. In this paper, the set of characteristics was selected so as to reflect the following input in the production process: land, labor, expenditure and capital, and three output variables: the value of crops, livestock, and other production.

All variables published in the FADN database refer to average holdings in each EU member state in 2012. The data published in the FADN can also be viewed on a more detailed level: for specific regions, economic sizes, and orientation of production. While the country-level means might 
Table 1. Data for EU agriculture in 2012 included in the analysis

\begin{tabular}{|c|c|c|c|c|c|c|c|}
\hline country & $\begin{array}{l}\text { crops } \\
{[1000 €]}\end{array}$ & $\begin{array}{c}\text { livestock } \\
{[1000 €]}\end{array}$ & $\begin{array}{c}\text { other } \\
\text { [1000€] }\end{array}$ & $\begin{array}{c}\text { labor } \\
\text { [AWU] }\end{array}$ & $\begin{array}{l}\text { agricul- } \\
\text { tural area }\end{array}$ & $\begin{array}{l}\text { total ex- } \\
\text { pendi- } \\
\text { ture } \\
{[1000 €]}\end{array}$ & $\begin{array}{c}\text { fixed } \\
\text { capital } \\
{[1000 €]}\end{array}$ \\
\hline & SE135 & SE206 & SE256 & SE010 & SE025 & SE270 & * \\
\hline BEL & 110.27 & 145.61 & 9.12 & 2.13 & 49.14 & 225.63 & 305.56 \\
\hline BGR & 28.81 & 11.00 & 1.26 & 2.47 & 35.71 & 38.98 & 30.23 \\
\hline CYP & 15.65 & 23.64 & 0.22 & 1.45 & 9.04 & 35.6 & 40.81 \\
\hline CZE & 188.27 & 119.39 & 31.16 & 6.57 & 227.86 & 375.65 & 587.23 \\
\hline DAN & 157.95 & 283.33 & 26.80 & 1.71 & 95.26 & 438.90 & 560.98 \\
\hline DEU & 115.42 & 123.32 & 20.64 & 2.22 & 85.57 & 245.5 & 234.32 \\
\hline ELL & 16.36 & 6.91 & 0.23 & 1.15 & 9.29 & 18.01 & 36.39 \\
\hline ESP & 31.11 & 18.13 & 0.52 & 1.40 & 38.65 & 38.94 & 48.12 \\
\hline EST & 57.42 & 44.29 & 8.22 & 2.01 & 125.87 & 112.89 & 132.02 \\
\hline FRA & 116.65 & 77.29 & 8.67 & 2.03 & 85.36 & 185.27 & 188.60 \\
\hline HUN & 43.63 & 22.29 & 4.41 & 1.58 & 46.26 & 65.97 & 61.42 \\
\hline IRE & 12.63 & 50.99 & 0.97 & 1.22 & 50.27 & 61.96 & 125.71 \\
\hline ITA & 37.17 & 16.03 & 2.00 & 1.26 & 15.34 & 37.89 & 66.55 \\
\hline LTU & 27.38 & 14.61 & 0.42 & 1.77 & 48.49 & 36.00 & 55.11 \\
\hline LUX & 45.04 & 115.66 & 22.14 & 1.78 & 79.09 & 204.03 & 476.32 \\
\hline LVA & 33.26 & 19.56 & 3.51 & 2.02 & 68.93 & 55.64 & 58.87 \\
\hline MLT & 16.13 & 21.74 & 0.22 & 1.39 & 2.62 & 33.00 & 89.71 \\
\hline NED & 216.60 & 214.59 & 51.10 & 2.76 & 35.65 & 432.24 & 521.98 \\
\hline OST & 22.12 & 36.62 & 15.70 & 1.41 & 31.46 & 65.47 & 253.20 \\
\hline POL & 17.27 & 13.47 & 0.38 & 1.73 & 18.84 & 25.73 & 59.63 \\
\hline POR & 16.28 & 12.01 & 1.47 & 1.59 & 24.19 & 24.40 & 33.13 \\
\hline ROU & 7.36 & 5.33 & 0.06 & 1.30 & 10.05 & 8.69 & 20.10 \\
\hline SUO & 52.25 & 46.60 & 5.99 & 1.30 & 54.73 & 133.78 & 163.65 \\
\hline SVE & 96.17 & 80.86 & 25.64 & 1.44 & 101.27 & 225.03 & 330.20 \\
\hline SVK & 301.48 & 127.51 & 92.57 & 13.73 & 521.5 & 675.46 & 383.57 \\
\hline SVN & 13.06 & 11.03 & 2.51 & 1.46 & 11.57 & 28.83 & 87.07 \\
\hline UKI & 118.02 & 130.09 & 14.00 & 2.23 & 161.13 & 254.38 & 252.01 \\
\hline UE28 & 37.94 & 29.58 & 3.73 & 1.56 & 32.65 & 62.47 & 85.37 \\
\hline
\end{tabular}

*SE450+SE455+SE460.

Source: FADN 
be excessively generalized, a decision was made to use this level nonetheless, considering the purpose of the present paper.

Labor inputs (labeled SE010 in FADN methodology) were expressed as the number of full-time employees working on a farm. The next production factor, i.e. land, was expressed as total utilized agricultural area in hectares (SE025) Other variables used in the analysis are numerical and expressed in thousands of euro. This includes the total input (SE270) and the value of fixed capital, which is the sum of the following values: buildings and fixed equipment belonging to the holding (SE450), machinery (SE455) and breeding livestock (SE460). Output variables, i.e. total output of crops (SE135), total output of livestock (SE206), and other output (SE 256) were defined the same way. Values of these variables for EU member states, with the appropriate international abbreviations, are presented in table 1.

The example refers to agricultural productivity, i.e. the size of the output compared to the input. It does not take into consideration the profitability of the production, which, considering the whole system of subsidies implemented within the CAP, is neither equal or similar to the approach presented here. However, continuing agricultural production in some areas despite low efficiency may be an indirect indication that the decisions made by farmers in this respect are affected by other economic factors.

\section{MULTI-VARIATE RANKING OF TECHNICAL EFFICEINCY IN UE AGRICULTURE}

Application of DEA enables the simultaneous analysis of efficiency for the four basic production factors and three outputs. Table 2 presents its results, assuming that production is oriented towards output maximization. Subsequent columns show the estimated technical efficiency for VRS, the assessed scale of production, and the difference between potential and actual output of each entity.

DEA results indicate that 18 out of 28 entities are efficient in their agricultural production. Leaders include large-scale agricultural holdings from: Slovakia, the Netherlands, Denmark, Belgium, Germany, France, Austria, and Ireland, as well as holdings from Italy, Spain, Bulgaria, Malta, Romania, Hungary, Cyprus, Greece, Portugal, and Sweden that are smaller on average. The three latter entities operated under conditions of 
Table 2. Ranking of technical efficiency of EU farms in 2012 and an indication of potential output

\begin{tabular}{|c|c|c|c|c|c|}
\hline \multirow{3}{*}{ Country } & \multirow{2}{*}{$\begin{array}{l}\text { Technological } \\
\text { efficiency }\end{array}$} & \multirow{2}{*}{$\begin{array}{c}\text { Scale } \\
\text { of production }\end{array}$} & \multicolumn{3}{|c|}{$\begin{array}{l}\text { Potential increase of the achieved output } \\
\qquad[1000 €]\end{array}$} \\
\hline & & & crops $[1000 €]$ & $\begin{array}{c}\text { livestock } \\
{[1000 €]}\end{array}$ & other $[1000 €]$ \\
\hline & TEv & & SE135 & SE206 & SE256 \\
\hline BEL & 1.000 & - & 0 & 0 & 0 \\
\hline BGR & 1.000 & - & 0 & 0 & 0 \\
\hline CYP & 1.000 & - & 0 & 0 & 0 \\
\hline DAN & 1.000 & - & 0 & 0 & 0 \\
\hline DEU & 1.000 & - & 0 & 0 & 0 \\
\hline ESP & 1.000 & - & 0 & 0 & 0 \\
\hline FRA & 1.000 & - & 0 & 0 & 0 \\
\hline HUN & 1.000 & - & 0 & 0 & 0 \\
\hline IRE & 1.000 & - & 0 & 0 & 0 \\
\hline ITA & 1.000 & - & 0 & 0 & 0 \\
\hline MLT & 1.000 & - & 0 & 0 & 0 \\
\hline NED & 1.000 & - & 0 & 0 & 0 \\
\hline OST & 1.000 & - & 0 & 0 & 0 \\
\hline ROU & 1.000 & - & 0 & 0 & 0 \\
\hline SVK & 1.000 & - & 0 & 0 & 0 \\
\hline ELL & 1.000 & irs & 0 & 0 & 0 \\
\hline POR & 1.000 & irs & 0 & 0 & 0 \\
\hline SVE & 1.000 & irs & 0 & 0 & 0 \\
\hline UKI & 1.000 & drs & 0.494 & 0.545 & 7.063 \\
\hline CZE & 0.996 & drs & 5.428 & 63.739 & 10.218 \\
\hline LUX & 0.964 & drs & 35.300 & 4.262 & 0.816 \\
\hline SUO & 0.962 & irs & 2.041 & 1.820 & 3.839 \\
\hline UE28 & 0.926 & irs & 3.050 & 2.378 & 0.300 \\
\hline POL & 0.916 & drs & 1.592 & 1.241 & 0.497 \\
\hline LVA & 0.907 & irs & 3.430 & 2.017 & 0.362 \\
\hline LTU & 0.877 & drs & 3.834 & 2.046 & 0.811 \\
\hline EST & 0.850 & drs & 10.150 & 7.829 & 1.453 \\
\hline SVN & 0.843 & irs & 2.425 & 5.050 & 0.466 \\
\hline
\end{tabular}

Source: own calculations based on FADN data 
increasing returns to scale, i.e. additional increase of the involved input would result with a more than proportional increase of the output.

Countries where average holdings turned out to be inefficient included: Slovenia, Estonia, Lithuania, (technological efficiency below 90\%), Latvia, Poland $(0,90<\mathrm{TEv}<0,95)$, Finland, Luxembourg, and the Czech Republic $\left(0,95<\mathrm{TE}_{\mathrm{v}}\right)$. British agriculture was the closest to the leaders. Each of the listed inefficient entities could, to a larger or lesser extent, increase its output. In absolute values, the largest increase should occur in the Czech Republic: in the output of livestock - EUR 63,000, crops - EUR 5,000 and other - EUR 10,000. In relative values, the largest changes should occur in "other" output. In Lithuanian, agriculture this type of output should increase by nearly 200\% (from a level of EUR 420 to EUR 1,231). In Polish holdings, "other" output should increase by nearly 130\%. Quantitative analysis also indicates that in Luxembourg, crop output should be higher at the given level of input (by nearly $80 \%$ ). Livestock output should increase the most in the Czech Republic and Slovenia.

Information on the scale of production in average holdings in the studied member states also turned out to be interesting. Lithuania, Estonia, Poland, the Czech Republic, and Luxembourg operate their agricultural production under the conditions of decreasing returns to scale. From the point of view of rational management, agriculture in these countries should decrease the scale of production in order to improve efficiency.

Apart from demonstrating positions in the ranking, DEA also allows for identifying the leaders to whom the inefficient entities are the closest. In order to do that, one must analyze non-zero values of co-efficients $\lambda$ for these inefficient entities (table 3). For six entities out of the inefficient ten, Italian and Dutch agriculture are the closest. Polish agriculture is the closest to three leaders: Italy, Ireland, and Romania. British agriculture should follow four leaders: Germany, Denmark, the Netherlands, and Belgium.

Much economic information is also provided by comparing input slacks vs. output slacks. Absolute values for the inefficient entities are presented in Table 4. Output slacks for crops were only found in Luxembourg. There, an average agricultural holding could produce more crops (up to a value of EUR 33,641) with the same input. At the same level of input, livestock output could be increased in holdings in the Czech Republic and, to some extent, in Slovenia. DEA found more output slacks in the area of "other" output. Only four entities: Estonia, Luxembourg, Latvia, and Slovenia were not found to have an output slack there. Other countries could increase "other" output while maintaining the same level of input. 
Table 3. Relationship between inefficient entities and leaders, and the values of non-zero coefficients $\lambda$ for EU farms in 2012

\begin{tabular}{|l|c|l|}
\hline country & TEv & \multicolumn{1}{|c|}{ Leaders $\left(\lambda_{\mathrm{i}}\right)$} \\
\hline LVA & 0.907 & $\begin{array}{l}\text { ITA (0.096); BGR (0.472); NED (0.039); POR (0.224); HUN (0.170); } \\
\text { SVK (0.000) }\end{array}$ \\
UE28 & 0.926 & NED (0.054); ITA (0.468); BEL (0.020); CYP (0.296); ESP (0.162) \\
EST & 0.850 & FRA (0.023); DEU (0.158); NED (0.082); ITA (0.507); HUN (0.229) \\
UKI & 0.996 & NED (0.019); BEL (0.031); DEU (0.919); DAN (0.030) \\
SUO & 0.962 & SVE (0.293); DAN (0.063); ITA (0.271); ELL (0.373) \\
LTU & 0.877 & CYP (0.091); ESP (0.319); ITA (0.520); ROU (0.069) \\
SVN & 0.843 & OST (0.180); MLT (0.280); ROU (0.205); ELL (0.335) \\
LUX & 0.964 & NED (0.128); DAN (0.245); OST (0.627) \\
POL & 0.916 & IRE (0.120); ITA (0.365); ROU (0.515) \\
CZE & 0.972 & FRA (0.229); NED (0.771) \\
\hline
\end{tabular}

Source: own calculations based on FADN data

Table 4. Output and input slacks for EU farms in 2012

\begin{tabular}{|l|c|c|c|c|c|c|c|c|}
\hline Country & \multirow{2}{*}{$\mathrm{TE}_{\mathrm{v}}$} & $\begin{array}{c}\text { crops } \\
{[1000 €]}\end{array}$ & $\begin{array}{c}\text { live- } \\
\text { stock } \\
{[1000 €]}\end{array}$ & $\begin{array}{c}\text { other } \\
{[1000 €]}\end{array}$ & $\begin{array}{c}\text { agri- } \\
\text { labor } \\
\text { [AWU] }\end{array}$ & $\begin{array}{c}\text { total ex- } \\
\text { cultur- } \\
\text { area } \\
\text { pendi- }\end{array}$ & $\begin{array}{c}\text { fixed } \\
\text { ture } \\
{[1000 €]}\end{array}$ & $\begin{array}{c}\text { capital } \\
{[1000 €]}\end{array}$ \\
\cline { 3 - 9 } EST & 1.000 & 0 & 0 & 0 & 0.384 & 89.013 & 0 & 0 \\
UKI & 1.000 & 0 & 0 & 7.004 & 0.018 & 77.356 & 0 & 0 \\
CZE & 0.970 & 0 & 60.298 & 9.319 & 3.977 & 180.820 & 0 & 141.640 \\
LUX & 0.964 & 33.641 & 0 & 0 & 0.124 & 31.445 & 0 & 113.211 \\
SUO & 0.962 & 0 & 0 & 3.605 & 0 & 11.433 & 23.255 & 0 \\
UE28 & 0.926 & 0 & 0 & 0 & 0.123 & 13.616 & 0 & 0 \\
POL & 0.916 & 0 & 0 & 0.462 & 0.454 & 2.034 & 0 & 9.919 \\
LVA & 0.907 & 0 & 0 & 0 & 0 & 35.861 & 0 & 0 \\
LTU & 0.877 & 0 & 0 & 0.752 & 0.445 & 26.647 & 0 & 0 \\
SVN & 0.843 & 0 & 3.001 & 0 & 0.165 & 0 & 0 & 0.096 \\
\hline
\end{tabular}

* SE450+SE455+SE460.

Source: own calculations based on FADN data 
In all holdings, except for Slovenian ones, slacks were found for agricultural area. Surpluses ranged between around 2 ha of agricultural area in Poland to 180 ha in the Czech Republic. Labor situation in average holdings in the studied countries was similar. Only in Finland and Latvia no slacks in the area of labor were found. The largest surplus of this production factor was observed in large-scale farming in the Czech Republic (3.977 AWU), the smallest - in large-scale British farming. The analysis of fixed capital showed slacks primarily in average holdings from the Czech Republic and Luxembourg. Inefficient use of working capital was only found for Finland.

\section{CONCLUSIONS}

Rankings of efficiency in multi-variate conditions usually pose difficulties. The article presented a non-parametric method (DEA) that allows for determining the technical efficiency of entities producing many products and engaging many production factors. The method was used to develop an efficiency ranking for the studied entities. Furthermore, the DEA method, as opposed to parametric methods based on production functions, also allows the researchers to choose the orientation of efficiency increases. They may either choose output maximization at the given level of input, or input minimization at the given level of output.

Furthermore, apart from dividing entities into efficient and inefficient, the method allows one to estimate the scale of inefficiency, and as a consequence, to estimate the potential production size resulting from a proportional input increase. Apart from demonstrating positions in the ranking, DEA also allows for identifying the leaders whom the inefficient entities should follow. From the perspective of the utility of findings, this information is useful, as it allows to realistically shape economic changes aiming at improving the production efficiency in the future.

Contrary to the parametric approach, though, DEA does not allow for generalized interpretation of the achieved results. Because of that, it is more frequently used to compare entities, not to describe economic processes. As already mentioned, the DEA method can be used to formulate recommendations for improving the efficiency of each studied entity. It must be remembered, though, that the initial estimation of technical efficiency must be adjusted for the values of the so-called input and output slacks. Only then the assessment is credible. 
In the case of EU agriculture, 18 out of 28 entities turned out to be leaders. This means that despite its diversity, EU agriculture is increasingly rationally managed. Among the inefficient entities, the lowest efficiency was found in average holdings in Slovenia, achieving $84 \%$ of the maximum efficiency. Among the leaders, the most frequent role models were Italy and the Netherlands. Both were found to be points of reference for 6 out of the 10 inefficient entities.

With regard to input slacks, most were found in the areas of land and labor, i.e. factors considered in economic theory to be less flexible than capital or expenditure. In the area of output, most slacks were found in the "other" output category, indicating that this is the area that EU holdings should develop currently.

\section{BIBLIOGRAPHY}

Ackrill R. (2000), The Common Agricultural Policy, Sheffield Academic Press, Sheffield.

Afriat S.N. (1972), Efficiency estimation of production functions, "International Economic Review" no. 13, p. 568-598.

Aigner D.J., Chu S.F. (1968), On estimating the industry production function, "American Economic Review" no. 58, p. 826-839.

Błażejczyk-Majka L. (2016): Polskie gospodarstwa mleczne w rankingu efektywności technicznej gospodarstw unijnych z wykorzystaniem modelu SE-CCR [Polish Dairy Farms in the Ranking of Technical Efficiency of EU Farms Using the SE-CCR Model]. „Problemy Rolnictwa Światowego" [Problems of World Agriculture], no. 16 (XXXI), issue 3, p. 20-34.

Charnes A., Cooper W.W., Rhodes E. (1978), Measuring the efficiency of decision making units, "European Journal of Operational Research" no. 2, p. 429-444.

Coelli T.J., Rao D.S.P., O’Donnell C.J., Battese G.E. (2005), An Introduction to Efficiency and Productivity Analysis (second eds.), Springer Science+Business Media, New York.

Ćwiąkała-Małys A., Nowak W. (2009), Sposoby klasyfikacji modeli DEA [Methods of classifying DEA models], "Badania Operacyjne i Decyzje" [Operational research and decisions], no. 3, p. 5-18.

Debreu G. (1951), The coefficient of resource utilization, "Econometrica" no. 19, p. 14-22.

Farrell M.J. (1957), The measurement of productive efficiency of production, "Journal of the Royal Statistical Society, Series A" no. 120(III), p. 253-281.

Førsund F.R., Sarafoglou N. (2002), On the origins of data envelopment analysis, "Journal of Productivity Analysis" no. 17, p. 23-40.

Fried H., Lovell K., Schmidt S. (2008), Efficiency and productivity, [in:] Fried H., Lovell K., Schmidt S. (ed.), "The Measurement of Productive Efficiency and Productive Growth", Oxford University Press, Oxford-New York.

Guzik B. (2009a), Podstawowe modele DEA w badaniu efektywności gospodarczej i społecznej [Basic DEA models in the assessment of economic and social efficiency], Wydawnictwo Uniwersytetu Ekonomicznego w Poznaniu, Poznań. 
Guzik B. (2009b), Podstawowe możliwości analityczne modelu CCR-DEA [Basic analytical capabilities of the CCR-DEA model], "Badania Operacyjne i Decyzje" [Operational research and decisions], no. 1, p. 55-75.

Koopmans T.C. (1951), An analysis of production as an efficient combination of activities, [in:] Koopmans T.C. (ed.), "Activity Analysis of Production and Allocation", Cowles Commission for Research in Economics Monograph no 13, Wiley, New York.

Lisowski M. (2014), Metoda Data Envelopment Analysis (DEA) w ocenie efektywności podmiotów [Data Envelopment Analysis in the assessment of efficiency], "Prace Naukowe Uniwersytetu Ekonomicznego we Wrocławiu no. 343. Modele zarządzania kosztami i dokonaniami", [Publications of the Wrocław University of Economics, no. 343, Models of cost and achievement management], p. 364-375.

Löthgren M., Tambour M. (1999), Productivity and customer satisfaction in Swedish pharmacies: A DEA network model, "European Journal of Operational Research" no. 115, p. 449458.

Rembisz W., Sielska A. (2012), Mikroekonomiczna funkcja produkcji - właściwości analityczne wybranych jej postaci [Microeconomic function of the production - analytical properties of its selected forms], Vizja Press \& IT, Warszawa.

Scippacercola S., Sepe E. (2014), Principal component analysis to ranking technical efficiencies through stochastic frontier analysis and DEA "Journal of Applied Quantitative Methods" no. 9(4), p. 1-9.

Świtłyk M. (1999), Zastosowanie metody DEA do analizy efektywności gospodarstw rolnych [Application of the DEA method to analyze the efficiency of agricultural holdings], "Zagadnienia Ekonomiki Rolnej" [Issues of agricultural management], no. 6, p. 2841.

Thanassoulis E., Portela M., Despić O. (2008), Data envelopment analysis: the mathematical programming approach to efficiency analysis, [in:] Fried H., Lovell K., Schmidt S. (ed.), "The Measurement of Productive Efficiency and Productive Growth", Oxford University Press, Oxford-New York.

Wroński P. (2011), Wykorzystanie analizy taksonomicznej do opracowania ranking miast Lubelszczyzny [Application of taxonomic analysis to develop the ranking of towns in Lublin region], "Prace Naukowe Uniwersytetu Ekonomicznego we Wrocławiu. Ekonometria (34)" [Publications of the Wrocław University of Economics in Wrocław. Econometrics (34), no. 200, p. 38-47.

Zhang W. (2015), The Analysis of the Agriculture Input and Output Efficiency Based on DEA Model, “Agricultural Science \& Technology” no. 16 (2), p. 414-416.

Common Agricultural Policy in figures, downloaded November 2017 from http:/ /www. europarl.europa.eu/atyourservice/pl/displayFtu.html?ftuId=FTU_5.2.10.html.

CEPA (2016). Center for Efficiency and Productivity Analysis. Downloaded March 2016 from http://www.uq.edu.au/economics/cepa/index.php

FADN (2015). Farm Accountancy Data Network. Downloaded July 2015 from http:// www.ec.europa.eu/agriculture/rica.

Lucyna Błażejczyk-Majka - PhD in economics, assistant professor at the Department of Economic History in the Institute of History, the Adam Mickiewicz University. Her scientific interests include quatitative methods in economic studies, particularly concerning EU agriculture. 